\title{
Chapter 18 \\ Promoting Life Cycle Thinking, Life Cycle Assessment and Life Cycle Management Within Business in Brazil
}

\author{
Marina Santa Rosa Rocha, Luiz Gustavo Ortega, Yuki Hamilton Onda Kabe, \\ Maria da Graça C.B. Popi, Felipe Duarte, and Maria Luisa Nerys
}

\begin{abstract}
The development of life cycle assessment in Brazil began in 1994 . Business companies were involved in this process by the government, and in this way life cycle management developed. To support and disseminate LCA and LCM, a group of nine companies created the Brazilian Business Network for LCA in 2013. In 2014, the Brazilian Business Council for Sustainable Development became the coordinator of the Network. Despite the many challenges in promoting the theme in Brazil, the Network is advancing and benefits from the representativeness of large companies and their power to push governments, peers and their value chains.
\end{abstract}

Keywords Brazilian Business Council for Sustainable Development - Life cycle assessment $\bullet$ Life cycle management

\section{Introduction}

The development of life cycle assessment (LCA) in Brazil began in 1994 with a subgroup to discuss the subject within the Supporting Group for Environmental Standardization (GANA, acronym in Portuguese). This group was supported by the

\footnotetext{
M.S.R. Rocha $(\bowtie)$

Brazilian Business Council for Sustainable Development, Rio de Janeiro, Brazil e-mail: marinasrosa@cebds.org

L.G. Ortega • Y.H.O. Kabe

Brakem, São Paulo, Brazil

Maria da Graça C.B. Popi

Oxiteno, São Paulo, Brazil

F. Duarte • M.L. Nerys

Vale, Rio de Janeiro, Brazil

(C) The Author(s) 2015

G. Sonnemann, M. Margni (eds.), Life Cycle Management,

LCA Compendium - The Complete World of Life Cycle Assessment,

DOI 10.1007/978-94-017-7221-1_18
} 
Brazilian Association of Technical Standards (ABNT, acronym in Portuguese) (Ribeiro and Cherubini 2014). This represented the first step towards the dissemination of LCA in Brazil.

After this, a few important guidelines and studies were developed until the creation of the Brazilian Life Cycle Association (ABCV, acronym in Portuguese) in 2002. This association aims at the dissemination and consolidation of life cycle management in Brazil, working along with businesses, academic institutions, governments and organized civil society (ABCV 2015, see Ribeiro and Cherubini 2014).

Four years later, in 2006, a project for constructing the Brazilian Life Cycle Database started. The governmental institution responsible for this project was the Brazilian Institute of Information on Science and Technology (IBICT, acronym in Portuguese), which is a federal institute associated to the Science, Technology and Innovation Ministry. In 2010 this project led to the creation of the Brazilian Life Cycle Assessment Program (PBACV, acronym in Portuguese). This program was approved by the National Council for Metrology, Standardization and Industrial Quality (IBICT 2015).

The coordination of the program was delegated to INMETRO (National Institute for Metrology, Standardization and Industrial Quality) in cooperation with IBICT. The objective of PBACV is to "support the sustainable development and the environmental competitiveness of the Brazilian industrial production and promote the access to internal and external markets" (BRASIL 2010b, see Ribeiro and Cherubini).

Despite all these activities and the involvement of some industries in PBACV, the engagement of some key businesses was still lacking. Therefore, some key companies created the group "Brazilian Business Network for LCA".

\section{Brazilian Business Network for Life Cycle Assessment}

The Brazilian Business Network for LCA was launched in 2013 by nine large companies in Brazil, namely Braskem, Danone, Embraer, GE, Grupo Boticário, Natura, Odebrecht, Oxiteno and Tetra Pak, in partnership with the Brazilian Life Cycle Association and Akatu Institute.

The first activity of the Network was to conduct a survey among its members to understand the main gaps in LCA development in the Brazilian business. The conclusions of the survey showed that the lack of experts and reliable data prevented further use of LCA and LCM in business. Thus, the Network defined its main goals as follows:

- To create an environment of cooperation between companies interested in using LCA in Brazil, allowing the optimization of resources

- To educate and qualify companies regarding the concept, application, and the benefits of LCA 
- To provide access and disseminate LCA information in Brazil through studies, good practices and specialists

- To influence and support governments to create a Brazilian LCA database

To be linked to an institution that have the representativeness in the sustainable development field and that could give support to the Network for achieving its goals turned out to be an interesting path. So, in 2014, the Brazilian Business Council for Sustainable Development (BCSD - Brazil) became the coordinator of the Network. BCSD-Brazil is a non-profit civil association that promotes sustainable development for companies that operate in Brazil by interacting with governments and civil society, being the representative in Brazil of the World Business Council for Sustainable Development (WBCSD) (CEBDS 2015).

Until May 2015, approximately 20 members joined the Network, amongst others, 3M do Brasil, Alcoa, Arcelor Mittal, BASF, Duratex, Klabin, Petrobras, Vale, Volkswagen and Votorantim Cimentos.

The company members have complex and extensive value chains which are key for the dissemination of life cycle thinking. So, they influence not only their value chains and peers, but also the governments and the civil society. In terms of actions to support and influence governments, the Network plays a key role in the development of the Brazilian Data Base which will enable access of trustful life cycle information regarding the Brazilian reality.

Through BCSD-Brazil, the Network has created a partnership with the United Nations Environmental Program (UNEP) and IBICT to build up the capacity of local specialists for the development and adaptation of datasets.

Not only specialists must be prepared to work with LCA but also corporate professionals should be aware of basic LCA and LCM concepts. In this sense, the Network has launched in October 2014 a 2-day course designed for a corporate audience which had Professor Cassia Ugaya, from Federal Technological University of Parana (UFTPR, acronym in Portuguese), as a trainer. The 2014 edition was well succeeded and had 36 participants from 23 companies from many different sectors like Adidas, KPMG and Caixa Econômica Federal (CEBDS 2014).

These two accomplishments were the result of the work developed by two of the Network's Working Groups (WG). In order to achieve its objectives the Network is divided into five WGs which are: Accreditation, Capacity Building and Professional Education, Communication, Data Base and Labelling. This division enables the development of specific projects on each key area for promoting LCM in Brazil.

\section{Implementing Life Cycle Assessment and Life Cycle Management Within Companies}

Incorporating life cycle thinking into company's management is a complex task, despite the benefits it can bring. The main challenges are: professional training, top leadership commitment, availability of sensitive data (regarding intellectual 
property) and mainly, for Brazil, to obtain realistic data. On the other hand, the major gain is the improvement of the decision-making process in order to achieve more sustainable practices, often related to an adequate use of resources and the risk prevention along the supply chain.

In this sense, Vale, a Brazilian mining company, has started to incorporate life cycle thinking into its processes. In 2013, an LCA study was completed for all pelletizing facilities in Brazil. With this study, Vale could identify internal best practices, which may become a reference for environmental issues assessed and be extended to other units, as well as adding value to pellet, raising its competitiveness in the medium- and long-term (Vale 2013).

Vale's goal is to work in an expanding environmental management strategy beyond the borders of Vale, positively influencing its supply chain. In 2015, the company is continuing to develop strategies to disseminate life cycle thinking across the whole company (Vale 2013).

Another example is Braskem, a petrochemical company, whose corporate strategy is based on the belief that chemistry and plastics make people's lifes better. This belief has led to the definition of a purpose: to develop sustainable solutions that make people's lives better. Both these statements are based on a life cycle perspective since it is in the use phase that most of the benefits of plastic products become apparent.

Life cycle management at Braskem began in 2004 with two eco-efficiency studies that led to improvements in their PVC production processes. Another ecoefficiency study led to the decision to invest in a bio-based polymer using sugar cane ethanol as feedstock: the I'm Green ${ }^{\mathrm{TM}}$ Polyethylene. Ten years later, more than 30 LCA studies have been conducted. These are used to aggregate sustainability as an added value to products and also to plastic solutions developed together with direct customers. Recently Braskem has used the company's Materiality Matrix to develop a single-score life cycle impact assessment method to help corporate decision making process by incorporating stakeholder opinion into a weighting scheme.

Braskem is also incorporating LCM. A qualitative assessment for the early stages of project development and for innovation processes has been developed. In addition, the company is currently working on extending it to incremental optimization projects of market development and application engineering.

\section{Conclusions}

Companies with a vision of the future are recognized as one of the main transformation drivers in our society. This has been proved by the development of LCA and LCM in the last years in Brazil, despite the many challenges it still faces.

The Brazilian experience is probably akin to several other countries, but it shows that transformation is greatly accelerated by the engagement of large companies which can move entire value chains. Societal transformation, however, requires academia, government, businesses and the general society working together. 
Open Access This chapter is distributed under the terms of the Creative Commons Attribution Noncommercial License, which permits any noncommercial use, distribution, and reproduction in any medium, provided the original author(s) and source are credited.

\section{References}

CEBDS (2014) http://cebds.org/noticias/rede-de-acv-promove-curso-de-capacitacao/\#.

VOdwwPnF_OM

CEBDS (2015) http://cebds.org/en/about-cebds/about-us/

IBICT (2015) http://acv.ibict.br/portal/comunidade/historico-acv

Ribeiro P, Cherubini E (2014) Projeto Diálogos Setoriais Brasil - União Europeia sobre Análise do Ciclo de Vida. Brasília, $171 \mathrm{p}$

Vale (2013) 2013 Sustainability report. Available at http://www.vale.com/EN/aboutvale/sustainability/Pages/default.aspx 